( Т. А. Роїк, д-р техн. наук, проф., О. А. Гавриш, д-р техн. наук, проф., Є. В. Штефан, д-р техн. наук, проф., О. П. Шостачук, старш. викл., КПІ ім. Ігоря Сікорського, Київ, Україна

\title{
ВПЛИВ АБРАЗИВНОГО ІНСТРУМЕНТУ ТА РЕЖИМІВ ШЛІФУВАННЯ \\ НА РІВЕНЬ КОНТАКТНИХ ТЕМПЕРАТУР КОМПОЗИЦІЙНИХ САМОЗМАЩУВАЛЬНИХ ДЕТАЛЕЙ ВУЗЛІВ ПОЛІГРАФІЧНИХ МАШИН
}

В статті представлено результати експериментальних досліджень особливостей утворення миттєвих контактних температур при шліфуванні робочих поверхонь композиційних самозмащувальних деталей на основі промислових шліфувальних відходів інструментальних сталей 7ХГ2ВМФ, Р7М2Ф6, 05Х12Н6Д2МФСГТ, призначених для оснащення важконавантажених вузлів тертя поліграфічної техніки.

Для формування високих параметрів якості робочих поверхонь деталей з нових композитів рекомендовано застосовувати шліфувальні круги на основі карбіду кремнію

зеленого (63C) на гліфталевій зв'язці з зернистістю 14-20 мкм.

Ключові слова: режими шліфування поверхонь; композитний матеріал; температурне поле; шліфувальний круг; зернистість; зв'язка; вузли поліграфічних машин.

\section{Постановка проблеми}

Питання еволюції техніки і, зокрема, однієї з важливих галузей поліграфічного машинобудування, передбачає підвищення якості високопродуктивного друкарського обладнання за рахунок одержання нових високоякісних деталей, що нерозривно пов'язано з проблемою розвитку новітніх технологій їх виготовлення і фінішної обробки робочих поверхонь [1, 2].

Окрім цього, сучасні вимоги потребують якісно нових матеріа- лів і нових методів тонкої обробки деталей з них, які поряд з традиційним комплексом фізикомеханічних властивостей мали б спеціальні функціональні характеристики, зокрема такі, що суттєво підвищують надійність та довговічність об'єктів поліграфічної техніки [1-3].

Слід відзначити, у машинобудівних галузях промисловості все більше уваги приділяється фінішним стадіям обробки деталей різного призначення, серед

() Автор(и) 2020. Видавець КПІ ім. Ігоря Сікорського.

CC BY 4.0 (https://creativecommons.org/licenses/by/4.0/). 
інших, деталям контактної взаємодії - антифрикційним деталям, що працюють у важких умовах експлуатації - за підвищених навантажень, температур, швидкостей обертання, у агресивному середовищі - на повітрі [1-4].

Для вузлів конструкцій новітнього обладнання друкарської техніки розроблено і запропоновано зносостійкі антифрикційні композиційні матеріали, які одержані з цінної та дешевої сировини - промислових шліфувальних відходів чорних металів, насамперед, легованих конструкційних сталей [4-8].

На основі розгалужених науково-дослідних робіт з розробки технології регенерації та повторного використання у виробничому циклі цих сировинних ресурсів в останні роки були створені оригінальні високозносостійкі самозмащувальні композити на основі інструментальних легованих сталей 7ХГ2ВМФ, Р7М2Ф6, 05Х12Н6Д2МФСГТ та ін. [1, 2, 9-13].

Розроблені композиційні антифрикційні деталі містять у своєму складі тверде мастило $\mathrm{CaF}_{2}$, вони є самозмащувальними і демонструють високі триботехнічні властивості за важких умов експлуатації вузлів друкарських машин, що, зокрема, дозволяє позбутися використання рідкого мастила і, відповідно, складних мастилоподавальних систем [1, 2, 9-14].

Такі деталі пройшли апробацію в умовах дії агресивного оточуючого середовища: кисень повітря, температурні навантаження при експлуатації до $450^{\circ} \mathrm{C}$, питомі навантаження до $7 \mathrm{MПа}$, швидкості обертання до 10000 об./хв. і були рекомендовані для виго- товлення деталей тертя (циліндричні втулки, пальці захоплювачів автооператорів, вісі підтримувачів кантувальних пристроїв вузлів переадресації готової продукції) поліграфічних машин типу KBA Rapida-6+L-NN-L, KBA Rapida 75-4, п'ятикольорових пристроїв Oce Arizona 6160 XTS та семикольорових Oce Arizona 6170 XTS, автоматичних машин світлодіодної сушки LED-UV офсетних друкарських машин фірми Air Motion System Europe (Швейцарія) тощо.

Для одержання високих параметрів якості деталей з нових композитів їх робочі поверхні піддаються надтонким методам абразивного оброблення (тонке шліфування, магнітно-абразивна обробка, суперфінішна доводка, хонінгування) $[1,2,15-17]$.

Авторами [1, 3, 18, 19] були проведені комплексні дослідження впливу складу абразивного інструменту та режимів різання при тонкому шліфуванні на параметри шорсткості $\mathrm{R}_{\mathrm{a}}$ робочих поверхонь нових композитів.

Проте ще й досі вельми обмежені відомості про дослідження температурних факторів тонкого абразивного шліфування, які мають безпосередній вплив на характер процесів, що відбуваються у поверхневих шарах при взаємодії з ріжучим інструментом, а відтак, і на параметри якості поверхонь обробки. На сьогодні існують лише окремі відомості щодо характеристик параметрів робочих поверхонь для деяких марок композиційних антифрикційних матеріалів під дією температурних полів у зоні шліфування [20]. 
Це обмежує можливості оптимізувати технологічні процеси тонкого абразивного шліфування робочих поверхонь тертя більш широкої номенклатури деталей з нових антифрикційних композиційних матеріалів задля забезпечення стабільно високих параметрів якості. Оскільки відомо, що параметри якості поверхонь при шліфуванні формуються в умовах одночасної дії силового та температурного полів, що виникають при зрізанні стружки загостреною вершиною кожного ріжучого зерна абразивного інструменту $[1-3,20]$.

Сили різання створюють залишкові напруження у поверхневому шарі оброблюваних деталей. При цьому при врізанні інструменту на оброблюваних поверхнях виникають миттєві температури внаслідок пластичних деформацій при зрізанні стружки і тертя абразивного зерна у контактних місцях зони шліфування. Ці миттєві контактні температури (температурне поле) спричинюють процеси відпуску (відпочинку) шару металу, що попередньо був зміцненим. Протікання одночасних процесів зміцнення та відпуску (відпочинку) шару оброблюваної деталі викликає формування кінцевих, остаточних величин параметрів шорсткості поверхні $\mathrm{R}_{\mathrm{a}}$ та фізичних властивостей шару (залишкових напружень, глибини та ступеня наклепу, глибини залягання наклепу) [1, 2, 21-25].

Тому визначення впливу складу абразивного інструменту та режимів різання на величини миттєвих контактних температур у зоні фінішної обробки композитних самозмащувальних антифрикційних деталей поліграфічної техні- ки, що виготовлені з широкої номенклатури шліфувальних відходів інструментальних сталей, $€$ актуальним науково-технічним завданням і потребує детальних досліджень.

Вирішення цього завдання відкриє можливості оптимізувати технологічні параметри фінішної обробки широкої номенклатури нових самозмащувальних композиційних деталей контактних пар задля одержання стабільно високих параметрів якості деталей важконавантажених вузлів друкарських машин.

\section{Мета роботи}

Встановлення впливу складу абразивного інструменту (матеріал зерна, зернистість шліфувального кругу, матеріал зв'язки) та режимів різання на рівень миттєвих контактних температур у зоні тонкого абразивного шліфування нових антифрикційних композитних деталей поліграфічних машин, що безпосередньо впливає на параметри якості їх робочих поверхонь.

\section{Результати проведених досліджень}

Експериментальні дослідження миттєвих контактних температур (температурного поля) при абразивній обробці нових композиційних деталей виконувались згідно з методикою, наведеною у роботах $[1,2,21]$.

Дослідження виконувались при зрізанні надтонких перерізів стружки, коли глибина шліфування перебуває у межах 0,0020,005 мм.

В експериментах використовувались зразки з новихантифрикційних композиційних матеріалів 
на основі шліфувальних відходів легованих інструментальних сталей наступного складу, мас. \%: 7ХГ2ВМФ + (5-8) $\mathrm{CaF}_{2} ;$ Р7M2Ф6 + + (5-8) $\mathrm{CaF}_{2}$ та 05Х12Н6Д2МФСГ + + (5-8) $\mathrm{CaF}_{2}[10,12,13]$.

Для визначення оптимальних режимів шліфування, які забезпечать отримання стабільно високих параметрів якості поверхні, були досліджені залежності величини миттєвих контактних температур, усереднених за шириною круга, від режимів різання при тонкому плоскому абразивному шліфуванні.

При виконанні досліджень перед кожним вимірюванням температур круг правився, потім деталь (зразок) шліфувалась начисто і проводилось виходжування протягом 3-5 проходів, таким чином всі круги мали приблизно однаковий ступінь затуплення.

У всіх експериментах використовувались шліфувальні круги з карбіду кремнію зеленого (63С), оскільки зерна карбіду кремнію зеленого (63C) мають найгост- рішу різальну кромку порівняно з зернами, наприклад, електрокорунду білого (23А) та монокорунду (M) [1, 2, 22-25].

У табл. 1-3 представлено результати досліджень миттєвих контактних температур, що виникають при абразивному шліфуванні нових композиційних матеріалів на основі шліфувальних відходів інструментальних сталей.

Як видно з табл. 1-3, тонке шліфування нових композитних матеріалів абразивними кругами 3 карбіду кремнію зеленого (63C) на гліфталевій зв'язці (Гл) при швидкості обертання шліфувального круга 22 м/с та глибинах шліфування 0,005-0,05 мм зумовлює виникнення в зоні обробки мінімальних температур (до $265^{\circ} \mathrm{C}$ ). Такі температури не чинять істотного впливу на фізико-механічні властивості металу. Наслідком цього є утворення найменших спотворень властивостей поверхневого шару деталі, а саме, залишкових напружень,

Таблиця 1

Миттєві контактні температури (T, $\left.{ }^{\circ} \mathrm{C}\right)$ при тонкій обробці зразків з 7ХГ2ВМФ + (5-8)\% $\mathrm{CaF}_{2}$

\begin{tabular}{|c|c|c|c|}
\hline \multirow{2}{*}{$\begin{array}{c}\text { Глибина шліфування } \\
\text { по лімбу верстата } \mathrm{t}_{л},\end{array}$} & \multicolumn{3}{|c|}{ Характеристика шліфувального круга } \\
\cline { 2 - 4 } & 63СМ14Гл & 63СМ14К16 & 63СМ20К16 \\
\cline { 2 - 4 } & \multicolumn{3}{|c|}{$\mathrm{T},{ }^{\circ} \mathrm{C}$} \\
\hline 0,005 & 120 & 170 & 225 \\
\hline 0,01 & 160 & 200 & 250 \\
\hline 0,02 & 195 & 255 & 390 \\
\hline 0,03 & 220 & 405 & 510 \\
\hline 0,05 & 260 & 510 & 640 \\
\hline
\end{tabular}

Примітка. Шліфувальний верстат FF-250 «Abawerk» (ФРН); швидкість круга $V_{\mathrm{k}}-22 \mathrm{~m} / \mathrm{c}$; швидкість виробу $\mathrm{V}_{\mathrm{B}}-2 \mathrm{~m} /$ хв.; охолодження $-3 \%$ розчин содової емульсії. 
Таблиця 2

Миттєві контактні температури $\left(\mathrm{T},{ }^{\circ} \mathrm{C}\right)$ при тонкій обробці зразків з Р7M2Ф6 + (5-8)\% $\mathrm{CaF}_{2}$

\begin{tabular}{|c|c|c|c|}
\hline \multirow{2}{*}{$\begin{array}{c}\text { Глибина шліфування } \\
\text { по лімбу верстата } \mathrm{t}_{л},\end{array}$} & \multicolumn{3}{|c|}{ Характеристика шліфувального круга } \\
\cline { 2 - 4 } & 63СМ14Гл & 63СМ14К16 & 63СМ20К16 \\
\hline 0,005 & 125 & 185 & 235 \\
\hline 0,01 & 170 & 210 & 260 \\
\hline 0,02 & 205 & 265 & 400 \\
\hline 0,03 & 230 & 425 & 540 \\
\hline 0,05 & 265 & 530 & 655 \\
\hline
\end{tabular}

Примітка. Шліфувальний верстат FF-250 «Abawerk» (ФРН); швидкість круга $\mathrm{V}_{\mathrm{k}}-22 \mathrm{~m} / \mathrm{c}$; швидкість виробу $\mathrm{V}_{\mathrm{B}}-2$ м/хв.; охолодження $-3 \%$ розчин содової емульсії.

глибини та ступеня наклепу, що виникають під дією сил різання.

Окрім цього, з погляду рівня миттєвих контактних температур використання абразивних інструментів саме на гліфталевій зв'язці дає кращі результати, ніж при застосуванні кругів на керамічній зв'язці (табл. 1-3).

Це пов'язано з такою властивістю гліфталевої зв'язки як ела- стичність. Тому сили різання, що виникають при зрізанні стружки, зменшують фактичну глибину врізання абразивного зерна у поверхневий шар матеріалу. У свою чергу, це змінює умови різання, а саме, суттєво зменшує переріз стружки, наслідком чого є зниження миттєвих контактних температур у зоні обробки і покращення умов формування рельєфу по-

Таблиця 3

Миттєві контактні температури $\left(\mathrm{T},{ }^{\circ} \mathrm{C}\right)$ при тонкій обробці зразків з матеріалу 05Х12Н6Д2МФСГТ + (5-8)\% $\mathrm{CaF}_{2}$

\begin{tabular}{|c|c|c|c|}
\hline \multirow{2}{*}{$\begin{array}{c}\text { Глибина шліфування } \\
\text { по лімбу верстата } \\
\text { мм }\end{array}$} & \multicolumn{3}{|c|}{ Характеристика шліфувального круга } \\
\cline { 2 - 4 } & 63СМ14Гл & $63 \mathrm{CM} 14 \mathrm{~K} 16$ & 63СМ20К16 \\
\hline 0,005 & 95 & 190 & 230 \\
\hline 0,01 & 105 & 205 & 325 \\
\hline 0,02 & 165 & 235 & 415 \\
\hline 0,03 & 180 & 395 & 570 \\
\hline 0,05 & 260 & 500 & 660 \\
\hline
\end{tabular}

Примітка. Шліфувальний верстат FF-250 «Abawerk» (ФРН); швидкість круга $\mathrm{V}_{\mathrm{k}}-22 \mathrm{M} / \mathrm{c}$; швидкість виробу $\mathrm{V}_{\mathrm{B}}-2 \mathrm{M} /$ хв.; охолодження $-3 \%$ розчин содової емульсії. 
верхні із забезпеченням високих параметрів шорсткості $\mathrm{R}_{\mathrm{a}}=0,62-$ 0,68 мкм.

На відміну від абразивних кругів на гліфталевій зв'язці застосування ріжучого інструменту на керамічній зв'язці (при всіх інших однакових режимах шліфування) призводить до істотного зростання температури в зоні контакту при фінішній обробці. Зростання температури залежно від зернистості інструменту і глибини шліфування в зоні контакту з поверхнею обробки сягає $>600^{\circ} \mathrm{C}$. Такі температури призводять до істотних структурних змін поверхневих шарів деталі, що проявляються у фазових перетвореннях складників матеріалу деталі, розпаду твердих розчинів, i, як наслідок, відбувається знеміцнення і незворотна пластична деформація поверхневих шарів оброблюваного матеріалу. Такі явища $є$ вкрай негативними, що суттєво знижують параметри якості поверхонь обробки.
Окрім дослідження впливу матеріалу зв'язки абразивного інструменту в роботі були виконані дослідження 3 оптимізації вибору зернистості абразивного інструменту. Попередніми експериментами було встановлено, що формування найкращих параметрів шорсткості поверхні нових композиційних матеріалів забезпечується застосуванням дрібнозернистих шліфувальних кругів [1-3]. Виконані експерименти дозволили встановити аналітичні залежності між параметрами шорсткості поверхні $\mathrm{R}_{\mathrm{a}}$ та розміром зерна абразивного інструменту [1-3].

Це стало мотивацією для вивчення впливу зернистості абразивного круга на миттєві контактні температури у зоні різання. Результати експериментів наведено у табл. 4.

Як видно з табл. 4, зменшення зернистості шліфувального круга (розміру зерна А) сприяє істотному зниженню величин

Таблиця 4

Вплив розміру зерна А при тонкому плоскому шліфуванні зразків з нових композитів на миттєві контактні температури $\left(\mathrm{T},{ }^{\circ} \mathrm{C}\right)$

\begin{tabular}{|c|c|c|c|}
\hline \multirow{2}{*}{$\begin{array}{c}\text { Розмір зерна } \mathrm{A} \\
\text { абразивного } \\
\text { інструменту, мкм }\end{array}$} & $\begin{array}{c}\text { 7ХГ2ВМФ+ } \\
(5-8) \% \mathrm{CaF}_{2}\end{array}$ & $\begin{array}{c}\text { Р7М2Ф6 }+ \\
(5-8) \% \mathrm{CaF}_{2}\end{array}$ & $\begin{array}{c}\text { 05Х12Н6Д2МФСГТ } \\
+(5-8) \% \mathrm{CaF}_{2}\end{array}$ \\
\cline { 2 - 4 } & \multicolumn{3}{|c|}{$\mathrm{T},{ }^{\circ} \mathrm{C}$} \\
\hline 50 & 260 & 240 & 220 \\
\hline 28 & 200 & 195 & 185 \\
\hline 20 & 140 & 160 & 120 \\
\hline 14 & 120 & 125 & 95 \\
\hline
\end{tabular}

Примітка. Шліфувальний верстат FF-250 «Abawerk» (ФРН); швидкість круга $\mathrm{V}_{\mathrm{k}}-22 \mathrm{~m} / \mathrm{c}$; швидкість виробу $\mathrm{V}_{\mathrm{B}}-2 \mathrm{~m} /$ хв; охолодження $-3 \%$ розчин содової емульсії, матеріал зерна абразиву - карбід кремнію зелений (63С); зв'язка круга - гліфталева (Гл). 
миттєвих контактних температур. Одержані результати дозволяють дійти висновку, що для мінімізації температурного впливу у зоні оброблення при тонкому абразивному шліфуванні нових композиційних матеріалів на основі шліфувальних відходів інструментального виробництва необхідно застосовувати дрібнозернисті інструменти з зернистістю в діапазоні 14-20 мкм.

Це дозволить уникнути незворотних фазово-структурних змін уповерхневих шарах деталі, текстурованості та анізотропії фізикомеханічних властивостей, і дозволить одержати стабільно високі параметри якості робочих поверхонь деталей друкарських машин.

\section{Висновки}

У роботі досліджено особливості виникнення миттєвих контактних температур при абразивному шліфуванні нових самозмащувальних антифрикційних композитів, одержаних на основі утилізованих та регенерованих шліфувальних відходів інструментальних сталей 7ХГ2ВМФ, Р7М2Ф6 та 05Х12Н6Д2МФСГТ з домішками твердого мастила $\mathrm{CaF}_{2}$, що призначені для оснащення важконавантажених вузлів поліграфічних машин.

Експерименти показали, що при шліфуванні композитів на величину температурного поля (миттєві контактні температури в зоні обробки) суттєво впливають матеріал абразивного зерна, зернистість інструменту та матеріал зв' язки шліфувального круга.
Аналіз результатів досліджень показав, що для формування високих параметрів якості робочих поверхонь деталей з нових композитів необхідно застосовувати шліфувальні круги на основі карбіду кремнію зеленого (63C) на гліфталевій зв'язці з зернистістю у межах 14-20 мкм. Це дозволяє уникнути значного підвищення температури в зоні обробки, фазово-структурних змін, незворотних пластичних деформацій, текстурованості і анізотропії властивостей в поверхневому шарі деталі, та забезпечити стабільно високі параметри якості поверхонь.

3 урахуванням температурного поля, що виникає в зоні фінішної обробки, високі параметри якості робочих поверхонь деталей 3 нових композитів на основі шліфувальних відходів інструментальних сталей можуть бути одержані 3 дотриманням наступних рекомендованих режимів різання: виконувати тонке абразивне шліфування при швидкості круга $\mathrm{V}_{\text {кр }}-22$ м/с, швид-

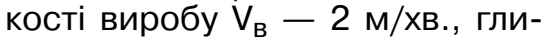
бині різання $\mathrm{t}=2-5$ мкм, охолодження - 3 \% розчин содової емульсії.

Наступні дослідження будуть спрямовані на вивчення процесів тонкого шліфування з використанням алмазного інструменту різної зернистості при фінішній обробці нових марок зносостійких самозмащувальних композиційних матеріалів для важконавантажених деталей друкарського обладнання.

\section{Список використаної літератури}

1. Шліфування і доводка зносостійких антифрикційних композитних деталей друкарських машин: монографія / [А. П. Гавриш, Т. А. Роїк, Ю. Ю. Віцюк та ін.]. ч. 1. К.: Видавничий дім «АртЕк», 2017. 208 с. 
2. Шліфування і доводка зносостійких антифрикційних композитних деталей друкарських машин: монографія / [А. П. Гавриш, П. О. Киричок, Т. А. Роїк та ін.]. ч. 2. К.: Видавничий дім «АртЕк», 2019. 132 с.

3. Прецизійна доводка та полірування деталей поліграфічних машин з високолегованих композитів: монографія / [А. П. Гавриш П. О. Киричок, Т. А. Роїк та ін.]. К.: НТУУ «КПІ», 2016. 498 с.

4. Композиційні підшипникові матеріали для підвищених умов експлуатації: монографія / [Т. А. Роїк, П. О. Киричок, А. П. Гавриш]. К.: НТУУ «КП|», 2007. 404 c.

5. Roik T. Using of composite materials for friction parts of printing equipment / T. Roik, lu. Vitsiuk // Металознавство та обробка металів. 2017. № 1. C. 33-38.

6. Роїк Т. А. Аналіз властивостей легованих композитів для деталей тертя друкарських машин / Т. А. Роїк, Т. М. Омік // Технологія і техніка друкарства. 2017. № 3(57). C. 20-30. DOI: https://doi.org/10.20535/2077-7264.3(57). 2017.121528.

7. Роїк Т. А. Ефективні композиційні антифрикційні матеріали на основі шліфувальних відходів сталі ШХ15СГ для середньоважких умов роботи / Т. А. Роїк, Ю. Ю. Віцюк // Наукові нотатки. 2018. № 61. С. 198-203.

8. Roik T. Tribotechnical Properties of Composite Materials Produced from ShKh15SG Steel Grinding Waste / T. Roik, O. Gavrysh, lu. Vitsiuk // Powder Metallurgy and Metal Ceramics: Springer Science + Business Media, LLC, Springer Nature 2019, New York. 2019. Volume 58(7). pp. 439-445. DOI 10.1007/s11106-019-00093w. First Online: 05 December 2019. https://link.springer.com/article/10.1007/s11106-019-00093-w.

9. Jamroziak K. New Antifriction Composite Materials Based On Tool Steel Grinding Waste / K. Jamroziak, T. Roik // WIT Transaction on Engineering Sciences, Volume 124, 2019: WIT-press, Material and Contact Characterisation IX, WIT Press Ashurst Lodge, Ashurst, Southampton, SO40 7AA, UK, Computational Mechanics International Inc 25 Bridge Street, Billerica, MA 01821, USA, ISBN: 978-1-78466-331-5 eISBN: 978-1-78466-332-2 ISSN: 1746-4471 (print) ISSN: 1743-3533 (on-line), pp. 151-159.

10. Антифрикційний композиційний матеріал на основі інструментальної легованої сталі: пат. 128694 Україна: МПК (2018.01) С22С33/02 / Т. А. Роїк, Ю. Ю. Віцюк, О. А. Гавриш. Заявка № u201713010 від 28.12.2017. Опубл. 10.10.2018. Бюл. № 19. С. 4.

11. Композиційний зносостійкий матеріал: пат. 122870 Україна: МПК C22C 21/02 (2018.01) / Т. А. Роїк, О. А. Гавриш, Ю. Ю. Віцюк. Заявка № u201708942 від 08.09.2017. Опубл. 25.01.2018. Бюл. № 2. С. 4.

12. Роїк Т. А. Антифрикційний композиційний матеріал на основі шліфувальних відходів інструментальної сталі для деталей друкарських машин / Т. А. Роїк, Ю. Ю. Віцюк // Міжвузівський збірник «Наукові нотатки». Луцьк. 2019. Вип. 68. С. $79 ? 85$.

13. Роїк Т. А. Структура і триботехнічні властивості композиційних антифрикційних матеріалів на основі відходів сталі Р7М2Ф6 / Т. А. Роїк, Ю. Ю. Віцюк, О. І. Хмілярчук // Наукові Вісті КПІ ім. Ігоря Сікорського. 2020. № 1. С. 54-60.

14. Композиційні підшипникові матеріали для підвищених умов експлуатації: монографія / [Т. А. Роїк, П. О. Киричок, А. П. Гавриш]. К.: НТУУ «КП।», 2007. $404 \mathrm{c}$.

15. Технологія поліграфічного машинобудування: навч. посіб. / [П. О. Киричок, Т. А. Роїк, А. В. Шевчук та ін.]. К.: НТУУ «КПІ», 2014. 504 с. 
16. Фінішне оброблення зносостійких деталей друкарських машин: навч. посіб. / [П. О. Киричок, Т. А. Роїк, А. П. Гавриш та ін.]. К.: НТУУ «КПІ», 2014. $404 \mathrm{c}$.

17. Новітні композиційні матеріали деталей тертя поліграфічних машин: монографія / [Т. А. Роїк, А. П. Гавриш, П. О. Киричок, Ю. Ю. Віцюк]. К.: НТУУ «KП।», 2014. 427 c.

18. Гавриш А. П. Вплив складу інструменту і режимів тонкого алмазного шліфування на шорсткість поверхні композитних підшипників ковзання поліграфічних машин / А. П. Гавриш, Т. А. Роїк, П. О. Киричок, Ю. Ю. Віцюк // Наукові вісті Національного технічного університету України «КПІ». 2013. № 5. С. $112-121$.

19. Гавриш А. П. Вплив фізико-механічних властивостей абразивних матеріалів на процес шліфування високолегованих композитів для поліграфічних машин / А. П. Гавриш, Т. А. Роїк, П. О. Киричок, О. О. Мельник, Ю. Ю. Віцюк // Технологія і техніка друкарства. 2015. № 3(49). C. 72-84. DOI: https://doi.org/10.20535/2077-7264.3(49).2015.54886.

20. Роїк Т. А. Температурне поле підшипників ковзання поліграфічних машин з високозносостійких композитів на основі інструментальних сталей і нікелю за умов тонкого абразивного шліфування поверхонь тертя / Т. А. Роїк, П. О. Киричок, О. С. Хлус, А. П. Гавриш // Технологія і техніка друкарства. 2016. № 2(52). C. 51-68. DOI: https://doi.org/10.20535/20777264.2(52).2016.77638.

21. Фінішна алмазно-абразивна обробка магнітних матеріалів: монографія / [А. П. Гавриш, П. П. Мельничук]. Житомир: ЖДтУ, 2004. 551 с.

22. Инструменты из сверхтвердых материалов / под ред. акад. НАН Украины Н. В. Новикова, д.т.н. С. А. Клименко. М.: Машиностроение, 2014. $607 \mathrm{c}$.

23. Лавриненко В. І. Надтверді абразивні матеріали в механообробні: Енциклопедичний довідник під заг. ред. акад. НАН України М. В. Новікова. К.: ІНМ НАН України, 2013. 456 с.

24. Основи теорії різання матеріалів / [М. П. Мазур, Ю. М. Внуков, В. Л. Доброскок, та ін.]; під заг. ред. М. П. Мазура. Львів: Новий світ, 2010. 423 с.

25. Сверхтвердые материалы. Получение и применение: монография в 6 т. / [под. общ. ред. Новикова Н. В.]. К.: ИСМ им. В. Н. Бакуля НАНУ, 2007. Т. 6: Алмазно-абразивный инструмент в технологиях обработки [под ред. А. А. Шепелева]. 340 c.

\section{References}

1. Havrysh, A. P. \& Roik, T. A. \& Vitsiuk, Yu. Yu. \& etc. (2017). Shlifuvannia $i$ dovodka znosostiikykh antyfryktsiinykh kompozytnykh detalei drukarskykh mashyn [Grinding and Finishing of Wear-Resistant Antifriction Composite Parts of Printing Machines]. part 1. Kyiv: Vydavnychyi dim 'ArtEk', 208 p. [in Ukrainian].

2. Havrysh, A. P. \& Kyrychok, P. O. \& Roi, T. A. \& etc. (2019). Shlifuvannia $i$ dovodka znosostiikykh antyfryktsiinykh kompozytnykh detalei drukarskykh mashyn [Grinding and Finishing of Wear-Resistant Antifriction Composite Parts of Printing Machines]. part 2. Kyiv: Vydavnychyi dim 'ArtEk', 132 p. [in Ukrainian].

3. Havrysh, A. P. \& Kyrychok, P. O. \& Roik, T. A. \& etc. (2016). Pretsyziina dovodka ta poliruvannia detalei polihrafichnykh mashyn z vysokolehovanykh kompozytiv [Precision Finishing and Polishing of Printing Machines Parts from High-Alloy Composites]. Kyiv: NTUU 'KPI', 498 p. [in Ukrainian]. 
4. Roik, T. A. \& Kyrychok, P. O. \& Havrysh, A. P. (2007). Kompozytsiini pidshypnykovi materialy dlia pidvyshchenykh umov ekspluatatsii [Composite Bearing Materials for Increased Operating Conditions]. Kyiv: NTUU 'KPI', 404 p. [in Ukrainian].

5. Roik, T. \& Vitsiuk, lu. (2017). Using composite materials for friction parts of printing equipment. Metaloznavstvo ta obrobka metaliv, 1, 33-38 [in English].

6. Roik, T. A. \& Omik, T. M. (2017). Analiz vlastyvostei lehovanykh kompozytiv dlia detalei tertia drukarskykh mashyn [Analysis of the Properties of High Alloyed Composites for Friction Parts of Printing Machines]. Tekhnolohiia $i$ tekhnika drukarstva, 3(57), 20-30. DOI: https://doi.org/10.20535/20777264.3(57).2017.121528 [in Ukrainian].

7. Roik, T. A. \& Vitsiuk, Yu. Yu. (2018). Efektyvni kompozytsiini antyfryktsiini materialy na osnovi shlifuvalnykh vidkhodiv stali SHH15SG dlia serednovazhkykh umov roboty [Effective Composite Antifriction Materials Based on Grinding Waste Steel for Medium Working Conditions. Naukovi notatky, 61, 198-203 [in Ukrainian].

8. Roik, T. \& Gavrysh, O. \& Vitsiuk, lu. (2019). Tribotechnical Properties of Composite Materials Produced from ShKh15SG Steel Grinding Waste. Powder Metallurgy and Metal Ceramics: Springer Science + Business Media, LLC, Springer Nature 2019, Vol. 58(7), 439-445. DOI 10.1007/s11106-019-00093w. Retrieved from https://link.springer.com/article/10.1007/s11106-019-00093-w [in English].

9. Jamroziak, K. \& Roik, T. (2019). New Antifriction Composite Materials Based On Tool Steel Grinding Waste. WIT Transaction on Engineering Sciences, Vol. 124, 151-159 [in English].

10. Roik, T. A. \& Vitsiuk, Yu. Yu. \& Havrysh, O. A. Antyfryktsiinyi kompozytsiinyi material na osnovi instrumentalnoi lehovanoi stali [Antifriction Composite Material Based on Tool Alloy Steel] // Patent UA № 128694. Publish 10.10.2018 [in Ukrainian].

11. Roik, T. A. \& Havrysh, O. A. \& Vitsiuk, Yu. Yu. Kompozytsiinyi znosostiikyi material [Composite Wear-Resistant Material] // Patent UA № 122870. Publish 25.01.2018 [in Ukrainian].

12. Roik, T. A. \& Vitsiuk, Yu. Yu. (2019). Antyfryktsiinyi kompozytsiinyi material na osnovi shlifuvalnykh vidkhodiv instrumentalnoi stali dlia detalei drukarskykh mashyn [Antifriction Composite Material Based on Grinding Waste of Tool Steel for Printing Machines Parts]. Naukovi notatky, 68, 79-85 [in Ukrainian].

13. Roik, T. A. \& Vitsiuk, Yu. Yu. \& Khmiliarchuk, O. I. (2020). Struktura i trybotekhnichni vlastyvosti kompozytsiinykh antyfryktsiinykh materialiv na osnovi vidkhodiv stali R7M2F6 [Structure and Tribotechnical Properties of Composite Antifriction Materials Based on Steel Waste R7M2F6]. Naukovi Visti KPI im. Ihoria Sikorskoho, 1, 54-60 [in Ukrainian].

14. Roik, T. A. \& Kyrychok, P. O. \& Havrysh, A. P. (2007). Kompozytsiini pidshypnykovi materialy dlia pidvyshchenykh umov ekspluatatsii [Composite Bearing Materials for Increased Operating Conditions]. Kyiv: NTUU 'KPI', 404 [in Ukrainian].

15. Kyrychok, P. O. \& Roik, T. A. \& Shevchuk, A. V. \& etc. (2014). Tekhnolohiia polihrafichnoho mashynobuduvannia [Technology of Printing Engineering]. Kyiv: NTUU 'KPI', 504 [in Ukrainian].

16. Kyrychok, P. O. \& Roik, T. A. \& Havrysh, A. P. \& etc. (2014). Finishne obroblennia znosostiikykh detalei drukarskykh mashyn [Finishing of Wear-Resistant Parts of Printing Machines]. Kyiv: NTUU 'KPI', 404 [in Ukrainian]. 
17. Roik, T. A. \& Havrysh, A. P. \& Kyrychok, P. O. \& Vitsiuk, Yu. Yu. (2014). Novitni kompozytsiini materialy detalei tertia polihrafichnykh mashyn [New Composite Materials for Friction Parts of Printing Machines]. Kyiv: NTUU 'KPI', 427 [in Ukrainian].

18. Havrysh, A. P. \& Roik, T. A. \& Kyrychok, P. O. \& Vitsiuk, Yu. Yu. (2013). Vplyv skladu instrumentu i rezhymiv tonkoho almaznoho shlifuvannia na shorstkist poverkhni kompozytnykh pidshypnykiv kovzannia polihrafichnykh mashyn [Influence of Tool Composition and Modes of Fine Diamond Grinding on Surface Roughness of Composite Plain Bearings of Printing Machines]. Naukovi visti Natsionalnoho tekhnichnoho universytetu Ukrainy 'KPI', 5, 112-121 [in Ukrainian].

19. Havrysh, A. P. \& Roik, T. A. \& Kyrychok, P. O. \& Melnyk, O. O. \& Vitsiuk, Yu. Yu. (2015). Vplyv fizyko-mekhanichnykh vlastyvostei abrazyvnykh materialiv na protses shlifuvannia vysokolehovanykh kompozytiv dlia polihrafichnykh mashyn [Influence of physical and mechanical properties of abrasives for polishing process of high-composites for printing machines]. Tekhnolohiia i tekhnika drukarstva, 3(49), 72-84. DOI: https://doi.org/10.20535/2077-7264.3(49).2015.54886 [in Ukrainian].

20. Roik, T. A. \& Kyrychok, P. O. \& Khlus, O. S. \& Havrysh, A. P. (2016). Temperaturne pole pidshypnykiv kovzannia polihrafichnykh mashyn z vysokoznosostiikykh kompozytiv na osnovi instrumentalnykh stalei i nikeliu za umov tonkoho abrazyvnoho shlifuvannia poverkhon tertia [Temperature Field of Printing Machine Slide Bearings Made from High Wear Resistant Composite Materials on the Base of Tool Steels and Nickel in Condition of Thin Abrasive Grinding of Friction Surfaces]. Tekhnolohiia i tekhnika drukarstva, 2(52), 51-68. DOI: https://doi.org/10.20535/2077-7264.2(52).2016.77638 [in Ukrainian].

21. Havrysh, A. P. \& Melnychuk, P. P. (2004). Finishna almazno-abrazyvna obrobka mahnitnykh materialiv [Finishing Diamond-Abrasive Processing of Magnetic Materials]. Zhytomyr: ZhDTU, 551 [in Ukrainian].

22. (2014). Instrumenty iz sverkhtverdykh materialov [Tools from Superhard Materials]. Moscow: Mashinostroenie, 607 [in Russian].

23. Lavrynenko, V. I. (2013). Nadtverdi abrazyvni materialy v mekhanoobrobni [Superhard Abrasive Materials in Machining]. Kyiv: INM NAN Ukrainy, 456 [in Ukrainian].

24. Mazur, M. P. \& Vnukov, Yu. M. \& Dobroskok, V. L. (2010). Osnovy teorii rizannia materialiv [Fundamentals of the Cutting Materials Theory]. Lviv: Novyi svit, 423 [in Ukrainian].

25. (2007). Sverkhtverdye materialy. Poluchenie i primenenie. Tom 6: Almazno-abrazivnyy instrument v tekhnologiyakh obrabotki [Superhard Materials. Obtaining and Application. Vol. 6: Diamond-Abrasive Tool in Processing Technologies]. Kyiv: ISM im. V. N. Bakulya NANU, 340 [in Russian].

The article presents the experimental research results of specific features of the instantaneous contact temperatures

formation at the working surfaces during grinding process of composite self-lubricating parts based on industrial grinding waste of tool steels 7KhG2VMF, R7M2F6 and 05Kh12N6D2MFSGT, intended for equipping of heavy-duty friction units in printing machines. It has been shown that during process of grinding composites the material of abrasive grain, the grain size of the tool and the grinding wheel's bonding material significantly affect the magnitude 
of the temperature field on the processing zone. It was recommended to use grinding wheels based on green silicon carbide (63C) on a glyphtale bond with a grain size of $14-20 \mu \mathrm{m}$ to form working surface's high quality parameters of the composite antifriction parts based on new materials. This allows to avoid an increase in temperature at the processing zone, which results to the significant phase-structural changes, plastic deformations and a decrease of the surface layer properties, and to ensure the working surface's stable high quality parameters of antifriction parts for printing machines.

Keywords: surface grinding modes; composite material; temperature field; grinding wheel; granularity; bond; units of printing machines. 